\title{
Phlebotominae Sand Flies in Paraguay. Abundance Distribution in the Southeastern Region
}

\author{
Oscar D Salomón/ ${ }^{+}$, Gustavo C Rossi*, Blanca Cousiño**, Gustavo R Spinelli***, \\ Antonieta Rojas de Arias**, Delfin G López del Puerto**, Arnaldo J Ortiz**
}

\begin{abstract}
Centro Nacional de Diagnóstico e Investigación en Endemo-Epidemias, Av. Paseo Colón 568, 1063, Buenos Aires, Argentina *Centro de Estudios Parasitológicos y de Vectores, La Plata, Argentina **Servicio Nacional de Erradicación del Paludismo-IICS, UNA, Asunción, Paraguay ***Facultad de Ciencias Naturales y Museo, Universidad Nacional de La Plata, La Plata, Argentina

From September 1993 to August 2001, 7,190 phlebotomine were collected with CDC light trap in an endemic area for human leishmaniasis, in the departments of Misiones and Itapúa, Paraguay. Eleven species were identified: Lutzomyia neivai (93.7\%), L. whitmani (4.1\%), and L. fischeri, L. shannoni, L. migonei, L. misionensis, L. cortelezzii, L. pessoai, L. alphabetica, Brumptomyia avellari and B. guimaraesi (less than 1\%). The last three species are new records for the country. The biodiversity and phlebotomine abundance were associated with the proximity to primary forest or gallery forest, but L. neivai was also found in peridomestic periurban environment. L. neivai was found throughout the year, and showed a period of higher activity from September to April (spring to fall) with a unimodal or bimodal pattern in relation to the annual rainy peaks during the summer. Background literature about phlebotomine from Paraguay has been reviewed.
\end{abstract}

Key words: Phlebotominae - Lutzomyia - vector ecology - Paraguay

The first reported outbreak of tegumentary leishmaniasis in Paraguay was in 1934 due to the Chaco war (González \& Oliveira y Silva 1939, González \& Arce Queirolo 1955b). Boggino and Mass (1945) recorded the first autochthonous case of visceral leishmaniasis. However, leishmaniasis had been already known in Paraguay for many decades (Migone 1913a,b, González \& Arce Queirolo 1955a). Leishmania (Viannia) braziliensis was isolated from cutaneous cases, while visceral and scarce cutaneous diffuse cases were ascribed to $L$. (L.) chagasi and $L$. (L.) amazonensis respectively (Grimaldi Jr et al. 1989). The incidence of tegumentary leishmaniasis ranged from 110 to 200 cases/year, but 900 to 1,600 cases were reported in 1982, 1985-1987, and 1991 periods (Arias et al. 1996). An outbreak of canine visceral leishmaniasis took place close to Asunción, the capital city in 1997 (Samudio et al. 1997, Canese 2000). Thus, leishmaniasis is an increasing public health problem in Paraguay.

Phlebotominae sand flies were reported by sporadic captures mostly in connection with leishmaniasis' foci. Seventeen species were identified, and Lutzomyia whitmani was found naturally infected by $L$. (V.) braziliensis (França 1920, Duret 1950, Del Ponte 1960, Martins et al. 1978, Rojas de Arias \& Ayala 1989, Inchausti et al. 1990, Inchausti \& Rojas de Arias 1991, Hashiguchi et al. 1992, Young \& Duncan 1994, Galati 2000).

This work was partially supported by the Entidad Binacional Yaciretá.

OD Salomón and GR Spinelli are members of "Carrera del Investigador Científico", Conicet.

+ Corresponding author. Fax: +54-11-4331.2536. E-mail: danielsalomon@hotmail.com

Received 3 June 2002

Accepted 21 November 2002
This study is the first report of serial Phlebotominae collections in Paraguay. It was carried out in the departments of Misiones and Itapúa, between 1993 and 2001. Previous and current results are discussed in order to understand sand fly abundance associations, with the purpose of contributing to the future design of surveillance strategies based on entomological data.

\section{MATERIALS AND METHODS}

Phlebotominae were collected at ten sites along the Paraná river, in the departments of Misiones (Coratei) and Itapúa (Ayolas, San Cosme-Damián, Carmen del Paraná, Quiteria, Aguapey, Encarnación, Bella Vista, Capitán Meza, Mayor Otaño), Paraguay (Fig. 1). Two CDC miniature light traps were used in parallel per site, both with $\mathrm{CO}_{2}(500 \mathrm{ml} /$ $\mathrm{h}$ ), placed $1.5 \mathrm{~m}$ above the ground. Captures were carried out monthly during $24 \mathrm{~h}$, from September 1993 to August 2001. Environmental characteristics of the sites are described in the discussion. Phlebotominae were processed and identified according to Young and Duncan (1994) and Marcondes (1996). Meteorological data were obtained from EBY Ituzaingó (Argentina). Fisher or $\chi^{2}$ tests were used for statistical analysis. All statistical tests were considered significant with 0.01 or less associated probabilities.

\section{RESULTS}

Considering 332 days of capture (141 positive) 7,190 specimens were collected (Table I). There were 8 out of the 17 species previously recorded for Paraguay, besides L. alphabetica, Brumptomyia avellari and B. guimaraesi, which represent new records for the country (Table II). The ecological environment of Ayolas, San CosmeDamián, Encarnación, Quiteria, Mayor Otaño, Capitán Meza, and Carmen del Paraná are similar and their phlebotomine abundance was low (82.9\% of collections with five or less sand flies), so the results of these sites were grouped (Table I). Encarnación had a maximum cap- 


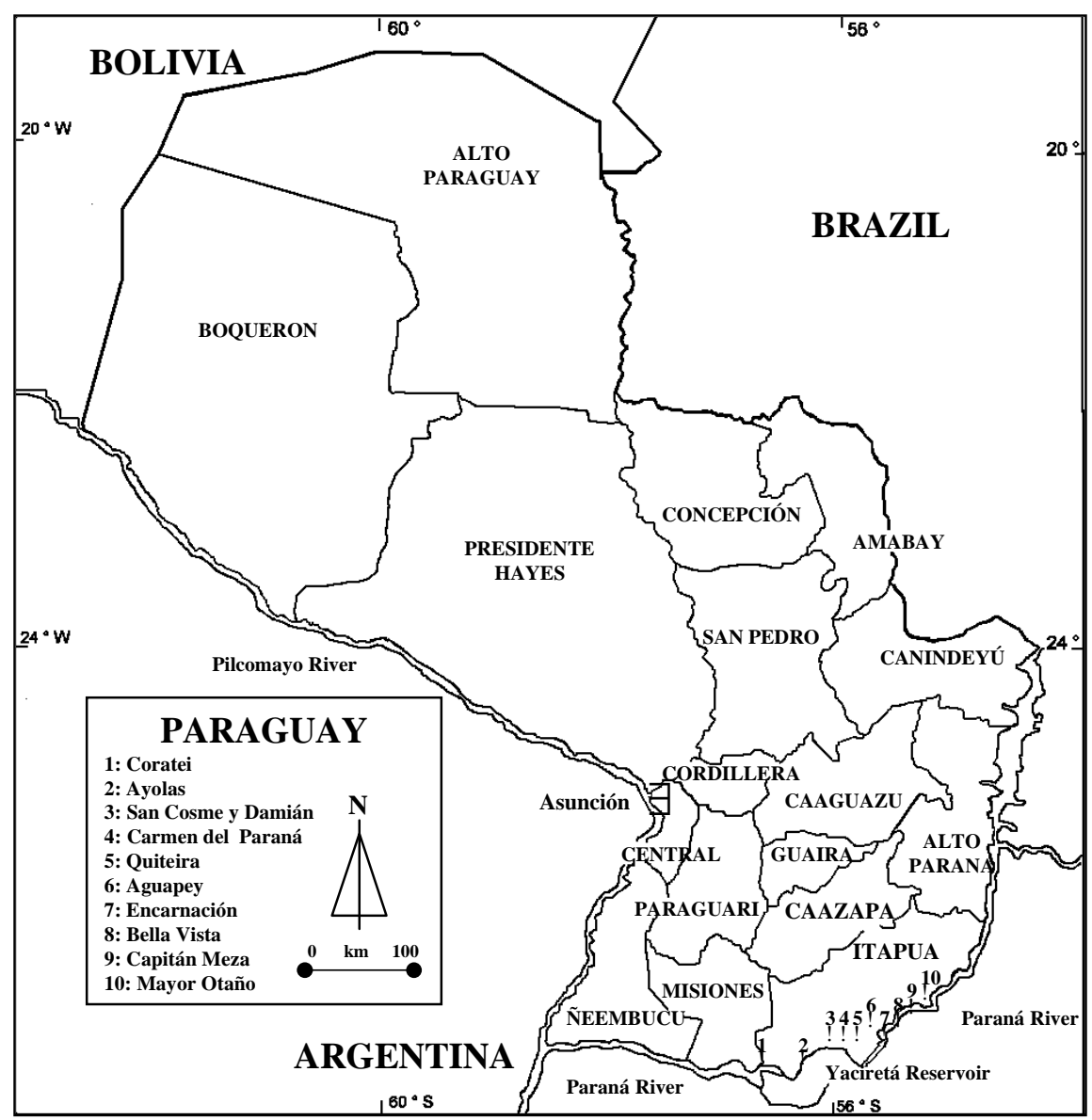

Fig.1: Phlebotominae collection sites with CDC light trap from 1993 to 2001, Paraguay.

ture of 16 phlebotomine/day and 64 L. neivai in the overall collection. No phlebotomine was obtained at the Carmen del Paraná site.

On the other hand, $97.1 \%$ of the sand flies were collected at the Coratei, Aguapey and Bella Vista sites. The total number of days when traps have been placed did not differ among the three stations, but the days with one or more sand flies collected were significantly different between Coratei (33.3\%) and Bella Vista (71.4\%), while Aguapey showed an in-between figure (49.2\%).

The predominant species was L. neivai in all the sites of capture. L. neivai Williams means in the three sites with largest collections were 0.66 in Coratei, 3.59 in Aguatey and 5.23 in Bella Vista. However, L. neivai female: male sex ratio in Bella Vista and Aguapey ranges from 1.4 to 1.6 , significantly different from the 2.1 ratio in Coratei. The relative abundance of species was different among the sites (Table I), L. neivai were collected with other species in Coratei, Aguapey and Bella Vista 4, 3 and 19 times respectively. In Bella Vista the lower relative abundance obtained in a single capture for L. neivai was $72.7 \%$, and it was found together with L. whitmani $(23.5 \%), L$. fischeri $(3.5 \%)$ and L. migonei $(0.3 \%)$. The four species with the highest captures besides $L$. neivai considering the overall collection were L. whitmani, L. fischeri, L. shannoni and L. migonei, their female: male sex ratios were $1.5,1.5,0.1$ and 0.5 , and they were found in $10,9,2$ and 9 times respectively.

L. neivai was collected throughout the year, but the highest captures were obtained between September and February. In Coratei and Aguapey a significant peak was observed in the 1999-2000 season (maximum November). In Bella Vista there were two peaks, the 1999-2000 peak (maximums December and February), but also a higher one during the 2000-2001 season (maximums October and February) (Fig. 2). L. neivai highest collection in a single capture were 258,666 and 922 sand flies for Coratei, Aguapey and Bella Vista respectively (ratio 1: 2.3: 3.6). $L$. neivai collections from September to February during the year with highest peaks were 358, 1,670 and 2,007 sand flies (ratio $1: 4.7: 5.6$ ). The other species were usually found together with L. neivai peaks.

\section{DISCUSSION}

Phlebotomine species diversity and relative abundance were similar among the collections in Misiones and Itapúa, Paraguay, and those reported previously from the Argentinean side of the common border (Salomón et al. 2002). In the latter, scarce captures of L. longipalpis were obtained (Salomón et al. 2001b), while L. alphabetica and L. cortelezzii were collected after the cited report (unpublished data). 
TABLE I

Phlebotominae species and species relative abundance (\%), collected with CDC light trap in Coratei, Aguapey, Bella Vista, and the remaining capture sites (Others), Paraguay, September 1993-February 2001

\begin{tabular}{|c|c|c|c|c|c|}
\hline Species & Coratei $(\%)$ & Aguapey (\%) & Bella Vista (\%) & Others & Total $(\%)$ \\
\hline L. neivai & $470(97.3)$ & 2527 (99.7) & 3541 (89.3) & $198(96.1)$ & $6736(93.7)$ \\
\hline L. pessoai & 0 & 0 & $8(0.2)$ & 0 & $8(0.1)$ \\
\hline L. fischeri & $2(0.5)$ & 0 & $52(1.3)$ & 0 & $54(0.7)$ \\
\hline L. migonei & $2(0.5)$ & 0 & $24(0.6)$ & $4(2.0)$ & $30(0.4)$ \\
\hline L. shannoni & 0 & 0 & $32(0.8)$ & 0 & $32(0.4)$ \\
\hline L. misionensis & 0 & 0 & $4(0.1)$ & 0 & $4(<0.1)$ \\
\hline L. whitmani & $2(0.5)$ & $6(0.2)$ & $287(7.2)$ & $2(1.0)$ & $297(4.1)$ \\
\hline L. cortelezzii & 0 & $2(<0.1)$ & $2(<0.1)$ & $1(0.5)$ & $5(<0.1)$ \\
\hline L. alphabetica & 0 & 0 & $3(<0.1)$ & 0 & $3(<0.1)$ \\
\hline B. avellari & $2(0.5)$ & 0 & 0 & $1(0.5)$ & $3(<0.1)$ \\
\hline B. guimaraesi & $5(1.3)$ & 0 & $13(0.3)$ & 0 & $18(0.2)$ \\
\hline Total & $483(100)$ & $2535(100)$ & $3966(100)$ & $206(100)$ & $7190(100)$ \\
\hline
\end{tabular}

L: Lutzomyia; B: Brumptomyia

The Bella Vista capture site was located at the dense forest near the Paraná river, the Coratei site was at modified vegetation close to residual patches of the Paraná gallery forest, and the Aguapey site was at the residual forest, $300 \mathrm{~m}$ from a water stream and $30 \mathrm{~m}$ from a house. Therefore, phlebotomine density and collection frequency correlated to the density of the vegetation coverage. The species diversity was positively associated with the vicinity of primary forest, as 10 out of the 11 species identified were in Bella Vista. Bella Vista had also the lowest $L$. neivai female: male ratio probably due to the closeness to the resting/breeding places. The low captures obtained in highly modified environments such as those grouped herein as "others" showed that sand flies might reach peridomestic habitats. Thus, the risk of humanphlebotomine effective contact is possible even in the vicinity of cities such as Encarnación. L. neivai, L. whitmani, and L. migonei were associated with peridomestic tegumentary leishmaniasis foci in Argentina (Salomón et al. 2001a,c-e, 2002).

L. neivai seasonal abundance showed activity from August-September to April-March (spring to fall) with a single peak or a bimodal pattern. Consistently, phlebotomine populations usually showed the highest density peaks during the warm-humid months, and the lowest in the cold-dry season, both in Brazil and Argen-

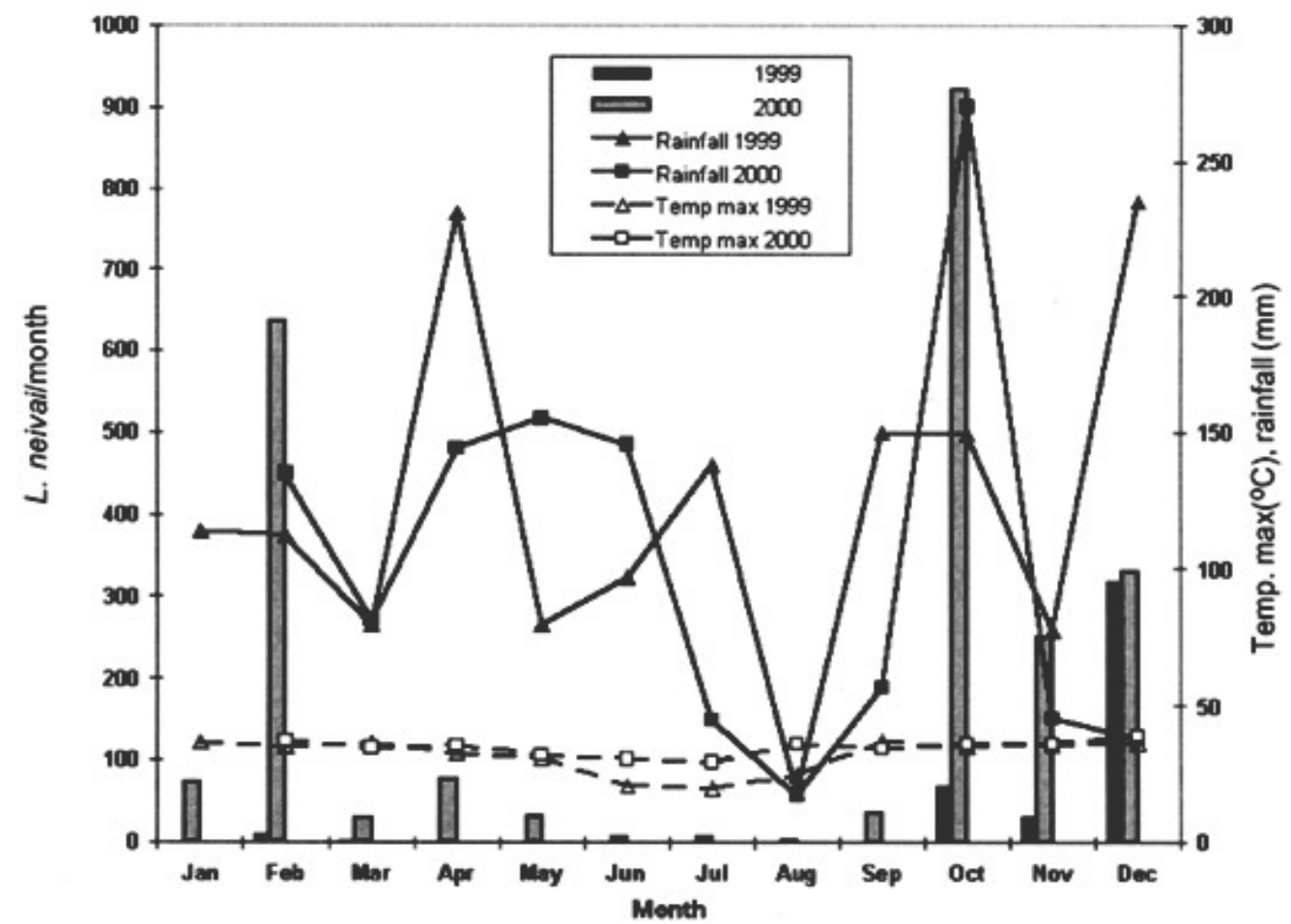

Fig. 2: Lutzomyia neivai abundance, maxima temperatures $\left({ }^{\circ} \mathrm{C}\right)$ and rainfall $(\mathrm{mm})$ by month during the year 1999 and 2000 . Bella Vista, Itapúa department, Paraguay. 
tina (Aguiar \& Soucasaux 1984, Gomes \& Galati 1987, Salomón et al. 2002), although the density is not always correlated with the rainfall and the temperature (Condino et al. 1998). The Bella Vista 2000-2001 peak may be due to the fact that sand flies were collected there during the winter of year 2000, captures not observed in other sites or years. Phlebotomine abundance peaks were associated with rainfall peaks. The 1999-2001 peaks were also observed in the captures at the Argentinean equivalent sites, and it was attributed to favorable climatic conditions (Salomón et al. 2001b, 2002).

Paraguay is a landlocked country ecologically divided in three main regions: (1) the densely wooded hills of the east and the Paraná river basin, with over 2,000 $\mathrm{mm}$ of rainfall per year; (2) the grassy plains, woody patches and marshes of the center and the Paraguay river basin, with $1600 \mathrm{~mm}$ of rainfall per year; (3) the dry forest and thorny scrub of the large arid region of the west (Chaco), with less than $800 \mathrm{~mm}$ of rainfall per year. Data from the Chaco region are scarce and in connection with the southern marshes of the Pilcomayo river basin. West to $61^{\circ} \mathrm{LW}$, 150 cases of tegumentary leishmaniasis were reported in 1934 during military activities carried out in the woods (Cañada del Carmen) (González et al. 1939, González \& Arce Queirolo 1955b).

The central region involves $20 \%$ of the territory and $80 \%$ of the country population and the highest number of leishmaniasis cases. Phlebotominae of this region were reported in the departments of San Pedro, Guaira, Caazapá, Caaguazú and Central (Table II). L. longipalpis was cap- tured recently during an outbreak of canine visceral leishmaniasis with Shannon traps during the evening (Samudio et al. 1997).

The eastern region belongs to the Amazonian domain (departaments of Itapúa, Misiones, and Alto Paraná) and showed the greatest phlebotomine biodiversity. $L$. alphabetica, B. avellari and B. guimaraesi reported here are the first records for the country. Between 1984 and 1985 an outbreak occurred in a recently settled locality (Tavapy II) in Alto Paraná, three man-biting sand fly species were identified L. intermedia s.l. (78.6\%), L. migonei (12.8\%) and L. whitmani (5.6\%) (Rojas de Arias \& Ayala 1989). Outbreaks of tegumentary leishmaniasis were also reported in recently settled communities at Limoy, Alto Paraná (Hashiguchi et al. 1991). At the Argentinean border an outbreak was also reported in 1997-1998 (Salomon et al. 2001d).

L. neivai (L. intermedia complex) was the prevalent species in all the sites sampled in the departments of Itapúa and Misiones. L. intermedia complex was recently differentiated in two species, $L$. intermedia sensu strictu and $L$. neivai (Marcondes 1996, Marcondes et al. 1998, Marcondes \& Borges 2000). The previous captures are referred here as L. intermedia s.l., although the specimens captured in Paraguay could be attributed to L. neivai considering the latitude and longitude where they were collected. L. intermedia s.l. and L. whitmani were both incriminated as vectors of $L$. braziliensis. L. whitmani is the most important species in residual forests or historical collections within the forest, while the relative abun-

TABLE II

Phlebotominae species by department or region (Chaco) reported in Paraguay ${ }^{a}$

\begin{tabular}{|c|c|c|c|c|c|c|c|c|c|c|}
\hline & 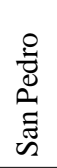 & 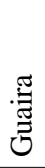 & 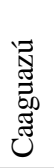 & 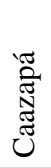 & 䒿 & 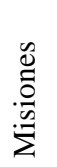 & 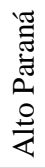 & 葛 & 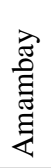 & $\begin{array}{l}\stackrel{8}{\mathscr{E}} \\
\text { U }\end{array}$ \\
\hline Lutzomyia alphabetica & & & & & $\mathrm{x}$ & & & & & \\
\hline Lutzomyia aragaoi & $\mathrm{x}$ & & & & & & & & & \\
\hline Lutzomyia cortelezzii & & & & & $\mathrm{x}$ & & $\mathrm{x}$ & & & \\
\hline Lutzomyia fischeri & $\mathrm{x}$ & & $\mathrm{x}$ & $\mathrm{x}$ & $\mathrm{x}$ & $\mathrm{x}$ & & & & \\
\hline Lutzomyia intermedia s.l. ${ }^{b}$ & $\mathrm{x}$ & $\mathrm{x}$ & $\mathrm{x}$ & $\mathrm{x}$ & $\mathrm{x}$ & $\mathrm{x}$ & $\mathrm{x}$ & & & $\mathrm{x}$ \\
\hline Lutzomyia lanei & $\mathrm{x}$ & & $\mathrm{x}$ & & & & & & & \\
\hline Lutzomyia longipalpis & $\mathrm{x}$ & $\mathrm{x}$ & & & & & & $\mathrm{X}$ & & \\
\hline Lutzomyia longispina & & & & & & & $\mathrm{x}$ & & & \\
\hline Lutzomyia lutziana & $\mathrm{x}$ & & & & & & & & & \\
\hline Lutzomyia migonei & $\mathrm{x}$ & & $\mathrm{x}$ & $\mathrm{x}$ & $\mathrm{x}$ & $\mathrm{x}$ & $\mathrm{x}$ & $\mathrm{x}$ & & $\mathrm{x}$ \\
\hline Lutzomyia misionensis & & & & & $\mathrm{x}$ & & & $\mathrm{x}$ & & \\
\hline Lutzomyia monticola & $\mathrm{x}$ & & $\mathrm{x}$ & & & & & & & \\
\hline Lutzomyia pessoai & $\mathrm{x}$ & & $\mathrm{x}$ & & $\mathrm{x}$ & & & & & $\mathrm{X}$ \\
\hline Lutzomyia sallesi & $\mathrm{x}$ & & & & & & & & & \\
\hline Lutzomyia shannoni & & $\mathrm{x}$ & $\mathrm{x}$ & $\mathrm{x}$ & $\mathrm{x}$ & & $\mathrm{x}$ & & $\mathrm{x}$ & \\
\hline Lutzomyia teratodes & & & & & & & & & & \\
\hline Lutzomyia walkeri & & & & & & & $\mathrm{x}$ & & $\mathrm{x}$ & \\
\hline Lutzomyia whitmani & $\mathrm{x}$ & $\mathrm{x}$ & $\mathrm{x}$ & $\mathrm{x}$ & $\mathrm{x}$ & $\mathrm{x}$ & $\mathrm{x}$ & & & \\
\hline Brumptomyia avellari & & & & & $\mathrm{x}$ & $\mathrm{x}$ & & & & \\
\hline Brumptomyia guimaraesi & & & & & $\mathrm{x}$ & $\mathrm{x}$ & & & & \\
\hline
\end{tabular}

$a$ : in the literature there are two more species that requires confirmation: Lutzomyia correlimai (Galati 2000), and Lutzomyia teratodes (Young \& Duncan 1994); b: L. intermedia sensu lato/L. neivai

Sources: Duret 1950, Martins et al. 1978, del Ponte 1960, Hashiguchi et al. 1991, 1992, Young \& Duncan 1994, this report. 
dance of L. intermedia s.l. was higher in peridomestic habitats in Brazil, in the state of Rio de Janeiro (Rangel et al. 1984, 1990, Oliveira-Neto et al. 2000, Souza et al. 2001), in the state of São Paulo (Forattini et al. 1972, Gomes et al. 1990, Gomes 1994, Tolezano 1994, Stolf et al. 1993, Casanova 2001) and in the state of Paraná (Teodoro \& Kuhl 1997), and in Argentina (Salomón 2001a-e, 2002). However, in a eastern primary forest reserve in the state of Paraná, Brazil, L. ayrozai and L. geniculata were the predominant species (Marcondes et al. 2001). On the other hand, L. whitmani was the prevalent species in peridomestic habitats of the state of Paraná, Brazil (Luz et al. 2000), and in human bait collections in Alto Paraná department, Paraguay (Hashiguchi et al. 1992), although in this department, in the Monday river, Rojas de Arias and Ayala (1989) found a higher proportion of L. intermedia s.l. biting humans near dwellings.

In conclusion, in the Southeastern region of Paraguay 11 phlebotomine species were identified. L. neivai was the prevalent species followed by L. whitmani. The proportion of the latter and the size of the overall collections increased in the vicinity of the residual primary forest or the secondary gallery forest. The sand fly population had peaks related to the warm-rainy months, when suspected vectors of $L$. braziliensis were found in peridomestic habitats and periurban collections. The species biodiversity is greater in this region than in other areas of Paraguay. Any surveillance strategy or control design in the area should take into account the different geographical lineage of sand fly complexes as that of $L$. intermediaL. neivai. That lineage may have different degrees of peridomestic adaptation, and therefore different Leishmania transmission associated risk.

\section{REFERENCES}

Aguiar GM de, Soucasaux T 1984. Aspectos da ecologia dos flebótomos do Parque Nacional da Serra dos Órgãos, Estado do Rio de Janeiro. I. Freqüência mensal em isca humana (Diptera, Psychodidae, Phlebotominae). Mem Inst Oswaldo Cruz 79: 197-209.

Arias JR, Beltrán F, Desjeux P, Walton B 1996. Epidemiología y Control de la Leishmaniasis en las Américas, por País o Territorio, Cuaderno Técnico OPS No 44, Organización Panamericana de la Salud, Washington, $52 \mathrm{pp}$.

Boggino J, Maas C 1945. Primer caso autóctono de leishmaniosis visceral. An Fac Clin Med (Asunción) 5: 319-326.

Canese A 2000. Leishmaniosis visceral canina en el área metropolitana de la "Gran Asunción", Paraguay. Medicina (Buenos Aires) 60 (Supl. 3): 65.

Casanova C 2001. A soil emergence trap for collections of phlebotomine sand flies. Mem Inst Oswaldo Cruz 96: 273275.

Condino MLF, Sampaio SMP, Henriques LF, Galati EAB, Wanderley DMV, Corrêa FMA 1998. Leishmaniose tegumentar americana: flebotomíneos de área de transmissão no município de Teodoro Sampaio, região sudoeste do Estado de São Paulo, Brasil. Rev Soc Bras Med Trop 31: 355-360.

Del Ponte E 1960. Distribución y conocimiento actual de la leishmaniasis en la Argentina. Primer Congreso Sudamericano de Zoología T1, p. 211-241.

Duret JP 1950. Nota sobre flebótomos y culícidos del Paraguay. Rev Sanidad Militar Argentina 49: 251-252.

Forattini OP, Pattoli DBG, Rabello EX, Ferreira AO 1972.
Infecção natural de flebotomíneos em foco enzoótico de leishmaniose tegumentar no Estado de São Paulo. Rev de Saúde Pública 6: 431-433.

França C 1920. Observations sur le genre Phlebotomus. II. Phébotomes du Nouveau Monde (Phlébotomus du Brésil et du Paraguay). Bull Soc Port Sci Nat 8: 215-236.

Galati EA 2000. Phlebotominae (Diptera, Psychodidae). Apostila Curso de Entomologia Médica 2000, São Paulo, p. $1-47$.

Gomes AC 1994. Sand fly vectorial ecology in the State of São Paulo. Mem Inst Oswaldo Cruz 89: 457-460.

Gomes AC, Coutinho SG, Paim GV, Oliveira SMO, Galati EAB, Nunes MP, Capinzaiki AN, Yamamoto YI, Rotter P 1990. Aspectos ecológicos da leishmaniose tegumentar americana. 8. Avaliação da atividade enzoótica de Leishmania (Viannia) braziliensis, em ambiente florestal e peridomiciliar, região do Vale do Ribeira, Estado de São Paulo, Brasil. Rev Inst Med Trop São Paulo 32: 105-115.

Gomes A de C, Galati EAB 1987. Aspectos ecológicos da leishmaniose tegumentar americana. 5. Estratificação da atividade espacial e estacional de phlebotominae (Diptera, Psychodidae) em áreas de cultura agrícola da região de Vale do Ribeira, Estado de São Paulo, Brasil. Mem Inst Oswaldo Cruz, 82: 467-473.

González G, Arce Queirolo A 1955a. Leishmaniosis . I. Historia de la leishmaniosis en el Paraguay. Rev Médica del Paraguay 1: 65-68.

González G, Arce Queirolo A 1955b. Leishmaniosis. II. Leishmaniosis cutáneo-mucosa y guerra en el Bosque. Rev Médica del Paraguay 1: 69-74.

González G, Oliveira y Silva M 1939. La leishmaniosis forestal americana en la guerra del Chaco. Novena Reunión Sociedad Argentina de Patología Regional 2: 959-974.

Grimaldi Jr G, Tesh RB, McMahon-Pratt D 1989. A review of the geographic distribution and epidemiology of leishmaniasis in the New World. Am J Trop Med Hyg 41: 687-725.

Hashiguchi Y, Arias O, Maciel D, Mansur J, Furuya M, Kawabata M 1991. Cutaneous leishmaniasis in south-eastern Paraguay: a study of an endemic area at Limóy. Trans $R$ Soc Trop Med Hyg 85: 592-594.

Hashiguchi Y, Chiller T, Inchausti A, Arias A, Kawabata M, Alexander JB 1992. Phlebotomine sandfly species in Paraguay and their infection with Leishmania. Ann Trop Med Parasitol 86: 175-180.

Inchaustti A, Rojas de Arias A 1991. Graphic key for identification of Paraguayan phebotomines. Annual Reports IICS: 774-784.

Inchausti A, Hashiguchi Y, Rojas de Arias A 1990. Phlebotomines of Paraguay species identification in three endemic areas. Diptera Psychodidae and Phlebotominae. Annual Reports IICS: 128-133.

Luz E, Membrive N, Castro EA, Dereure J, Pratlong F, Dedet JA, Pandey A, Thomaz-Soccol V 2000. Lutzomyia whitmani (Diptera: Psychodidae) as vector of Leishmania (V.) braziliensis in Paraná state, southern Brazil. Ann Trop Med Parasitol 94: 623-631.

Marcondes CB 1996. Redescription of Lutzomyia (Nyssomyia) intermedia (Lutz \& Neiva, 1912), and resurrection of $L$. neivai (Pinto, 1926) (Diptera, Psychodidae, Phlebotominae). Mem Inst Oswaldo Cruz 97: 457-462.

Marcondes CB, Borges PSS 2000. Distinction of males of the Lutzomyia intermedia (Lutz \& Neiva, 1912) species complex by ratios between dimensions and by an artificial neural network (Diptera: Psychodidae, Phlebotominae). Mem Inst Oswaldo Cruz 95: 685-688.

Marcondes CB, Lozovei AL, Vilela JH 1998. Distribução geográfica de flebotomíneos do complexo Lutzomyia 
intermedia (Lutz \& Neiva, 1912) (Diptera, Psychodidae). Rev Soc Bras Med Trop 31: 51-58.

Marcondes CB, Santos-Neto LG, Lozovei AL 2001. Ecology of phlebotomine sandflies (Diptera, Psychodidae) in Brazilian Atlantic Forest. Rev Soc Bras Med Trop 34: 255-260.

Martins AV, Williams P, Falcão AL 1978. American Sand Flies (Diptera:Psychodidae, Phlebotominae), Academia Brasileira de Ciências, Rio de Janeiro,195 pp.

Migone LE 1913a. La buba du Paraguay, leishmaniose americaine. Bull Soc Pathol Exot 6: 210-218.

Migone LE 1913b. Un cas de kala-azar a Asunción, Paraguay. Bull Soc Pathol Exot 6: 118-120.

Oliveira-Neto MP, Mattos MS, Perez MA, Da-Cruz AM, Fernandes O, Moreira J, Gonçalves-Costa SC, Brahin LR, Menezes CR, Pirmez C 2000. American tegumentary leishmaniasis (ATL) in Rio de Janeiro State, Brazil: main clinical and epidemiological characteristics. Int J Dermatol 39: 506514.

Rangel EF, Azevedo ACR, Andrade CA, Souza NA, Wermelinger ED 1990. Studies on sandfly fauna (Diptera:Psychodidae) in a focus of cutaneous leishmaniasis in Mesquita, Rio de Janeiro State, Brazil. Mem Inst Oswaldo Cruz 85: 39-45.

Rangel EF, Souza NA, Wermelinger ED, Barbosa AF 1984. Infecção natural de Lutzomyia intermedia (Lutz \& Neiva, 1912), em área endêmica de leishmaniose tegumentar no estado do Rio de Janeiro. Mem Inst Oswaldo Cruz 79: 395396.

Rojas de Arias A, Ayala F 1989. Flebótomos antropofílicos del Paraguay. Mem Inst Invest Cs de la Salud 8: 224-217.

Salomón OD, Bogado de Pascual M, Molinari ML, Verri V 2001a. Study of a cutaneous leishmaniasis outbreak in General Vedia, Province of Chaco, 1996. Rev Inst Med Trop São Paulo 43: 99-104.

Salomón OD, Rossi GC, Spinelli GR 2002. Ecological aspects of phelobotomine (Diptera, Psychodidae) in an endemic area of tegumentary leishmaniasis in the Northeastern Argentina, 1993-1998. Mem Inst Oswaldo Cruz 97: 163-168.

Salomón OD, Rossi G, Sosa Estani S, Spinelli G 2001b. Presen- cia de Lutzomyia longipalpis y situación de la leishmaniosis visceral en Argentina. Medicina (Buenos Aires) 61: 174178.

Salomón OD, Sosa Estani S, Canini L, Córdoba Lanús E 2001c. Leishmaniosis tegumentaria en un área con niveles epidémicos de transmisión, Salta, Argentina, 1998. Medicina (Buenos Aires) 61: 284-290.

Salomón OD, Sosa Estani S, Monzani AS, Studer C 2001d. Brote epidémico de leishmaniosis tegumentaria en Puerto Esperanza, provincia de Misiones, 1998. Medicina (Buenos Aires) 61: 385-390.

Salomón OD, Zaidenberg M, Burgos R, Heredia VI, Caropresi SL 2001e. American cutaneous leishmaniasis outbreak, Tartagal city, province of Salta, Argentina, 1993. Rev Inst Med Trop São Paulo 43: 105-108.

Samudio M, Schinini A, Inchaustti A, Cálcena MF, Avalos A, Rojas de Arias A 1997. Leishmaniasis visceral urbanizada en Asunción y ciudades vecinas. Rev Soc Bras Med Trop 30 (Supl. 1): 179.

Souza NA, Andrade-Coelho CA, Vilela ML, Rangel EF 2001. The Phlebotominae sand fly (Diptera: Psychodidae) fauna of two Atlantic Rain Forest Reserves in the State of Rio de Janeiro, Brazil. Mem Inst Oswaldo Cruz 96: 319-324.

Stolf HO, Alencar Marques S, Marques MEA, Yoshida ELA, Dillon NL 1993. Surto de leishmaniose tegumentar americana em Itaporanga, São Paulo (Brasil). Rev Inst Med Trop São Paulo 35: 437-442.

Teodoro U, Kuhl JB 1997. Interação flebotomíneos, animais domésticos e dominância de Lutzomyia (Nyssomyia) intermedia (Lutz \& Neiva, 1912) em área com alto grau de antropia, no Sul do Brasil. Rev Saúde Pública 31: 512-516.

Tolezano JE 1994. Ecoepidemiological aspects of American cutaneous leishmaniasis in the State of São Paulo, Brazil. Mem Inst Oswaldo Cruz 89: 427-434.

Young DG, Duncan MA 1994. Guide to the identification and geographic distribution of Lutzomyia sand flies in Mexico, the West Indies, Central and South America (Diptera: Psychodidae). Mem Amer Ent Inst 54: 1-881. 